\title{
From building construction waste into a house of creativity: a case of adapted reuse
}

\author{
Y. Kusumarini ${ }^{1}$, P. Mintarga ${ }^{2} \&$ T. N. Puji Utomo ${ }^{3}$ \\ ${ }^{1}$ Interior Design Department, Petra Christian University, Indonesia \\ ${ }^{2}$ Prima Putra Bengawan and Rempah Rumah, Indonesia \\ ${ }^{3}$ Interior Architecture Department, Universitas Ciputra, Indonesia
}

\begin{abstract}
The waste of building construction materials usually consist of iron and wood, which are frequently in the form of bits and pieces and thus appear to be unuseful for future building construction. Generally, they can only be used to create small products such as art and craft. Challenging this issue, this paper explores the case of using waste materials from building construction to become new building construction materials by specific treatments and experimental techniques of architectural design. The design thinking process and the effort in actualizing a House of Creativity named "Rempah Rumah Karya" became the objects of this exploration study. Discussions are presented here as efforts to explore ideas, processes, and actualization techniques in the context of reusing waste materials. The result is a self-critical design report of the aesthetically unique building design as a place of creativity and cultural activities in the city of Solo, Central Java, Indonesia.
\end{abstract}

Keywords: construction waste, house of creativity, re-use, design thinking.

\section{Introduction: waste materials as a problem}

Waste materials often become a problem in every production process and building construction. As an example, the Prima Putra Bengawan, a company located in the city of Solo, Central Java, Indonesia, produces environmental friendly furnishings for export markets and works on space-building construction projects both in Indonesia and abroad.

Prima Putra Bengawan produces furnishing for home, office, and hospitality applications: chairs, benches, storage, partitions, wood carving, table lamps, and 
bathroom accessories. All pieces are made of reclaimed wood that is certified by an internally Recognized Standard for Responsible forest management (Forest stewardship Council ${ }^{\mathrm{TM}}$ or FCS ${ }^{\mathrm{TM}}$, a certificate: SW-CoC-003 069). Reclaimed wood used for timber production is used on the former bridge constructions, railway sleepers, fishing boats and houses. The wood is shaped into innovative products designed by maintaining the natural quality of materials and construction functions of the previous history.

In addition to producing environmental-friendly furnishings, Putra Prima Bengawan also works on some space-building construction projects, including "Gourmet Garage Resto" Jakarta, Indonesia; "Shangrila Hotel" Los AngelesUSA; "Liebevoll Restorant" Dusseldorf, Germany; "Kagetsu" AmsterdamNetherland; "Loving Hut restaurant" Solo-Indonesia; "House Turi Boutique Hotel" Solo-Indonesia; and "Private Residences" Solo-Indonesia [1].

Both areas of work are certainly generating waste materials from the production and construction processes. Waste materials from the furnishing production and demolition projects as well as the other projects mainly consisting of wood and iron would always be produced and collected at the end, accumulating more and more waste materials in the company warehouse. This becomes a problem when the lease of the warehouse runs out and could not be extended. As an alternative solution, another warehouse would be rented to accommodate all the waste materials or to build another new warehouse.

After reflecting on the problem and considering alternative solutions, the basic step took was to look at the core of the problem: the accumulated waste production and construction materials. After giving attention to the core of the problem, the next step was determining the action: to make a detail inventory of all the existing waste materials. Following that was the decision to build a space-building that not only could be the solution of existing problems, but also be beneficial to the interests of the ecologic, social, cultural, and economic groups. Finally, the form of solution chosen was to build the space-building of 'Rempah Rumah Karya'.

This paper describes and discusses the actualization process of the 'Rempah Rumah Karya' in order to share experiences of real design practices with theoretical and scientific packaging in the field of design. The process of design thinking was chosen to describe the experience of scientific practice in architecture and interior design. The goal is to encourage design practical experiences that produce ecological, social cultural and economical space-building, which could be a beacon of learning and an object of observation as well as evaluation for scientific related fields (product design, interior design, and architecture).

\section{Design thinking process of 'Rempah Rumah Karya'}

Design thinking is an approach to solve problems. Design thinking applies and is widely used as an approach to solve problems in various fields, such as design (architecture, interior design, visual communication design, product design, etc.), and business (primarily the development of products and services). There are many literatures about the design thinking that has been developed in accordance with the field of design and business. 
Design thinking principally begins with a clear introduction of the problem, followed by the next step towards idea establishment, and concludes with the development of ideas in the design embodiment. Often, it is also continued by evaluation for the optimalization of the generated design embodiments. Several stages of design thinking or design process or method include:

- Discovery, Interpretation, Ideation, Experimentation, Evolution [2]

- Understand, Observe, Conceptualize, Validate, Implement [3]

- Inspiration, Ideation, Implementation [4]

- Define, Research, Ideate, Prototype, Select, Implement, Learn [5]

- Assimilation, General Study, Development, Communication [6]; etc.

The process of design thinking of the object 'Rempah Rumah Karya' was described by adopting the design process according to the Riverdale \& IDEO, starting from discovery, interpretation, ideation, experimentation and evolution. Plot design was adopted by the thinking process of adjusting needs in the context of outlining the process for the design of space-buildings objects that have come into being. Here are the stages of the design thinking process with adjustment:

- Discovery: the observation and discovery stages of the main issues that need to be resolved with design solutions.

- Interpretation: the stage of thinking to determine the relationship between problems with alternative design solutions that could be raised.

- Ideation: a step exploring ideas, concepts, and or a schematic design that could be considered to accommodate the design solution of the problem.

- Experimentation: the testing stage of design ideas in real forms, both in terms of construction and aesthetics.

- Evolution: the stage of embodiment of efforts of the real design from the test results in the experimentation stage.

Each stage of the design thinking represents what has been done since the problem identification stage to the actualisation of the object 'Rempah Rumah Karya' as a solution. This covers not only as a solution to the problems identified earlier from the pile of the waste construction material, but also the solution to social problems, creativity, and culture. Below is a description of the process of design thinking of 'Rempah Rumah Karya':

\subsection{Discovery}

Discovery was initiated by thinking about the problems of production and construction waste materials that have been accumulated and the knowledge of the case of Putra Prima Bengawan company's warehouse in which the rent could no longer be extended. The general solution is to move the pile of construction waste material into a new and larger warehouse. However, this general solution would only delay the problem further, because it will also remain the same problem in the future. The source of the problem is the accumulation of waste material, which 
if only given a conventional solution (i.e to store them in a space-building) will only raise the same issue at a later date. Other alternative solution is to build a warehouse to resolve the accumulation of waste material.

It was also found that there are two aspects to consider regarding the thinking process to solve the problem: the pile of the waste material and space-building requirements. Alternative solution started with partial thinking of each aspect (waste material or space-building) which would still be unable to produce the optimal solution. The subsequent thinking process focused on problem solving by integrating holistic ideas simultaneously to both aspects.

How do we eliminate the problem of piles of waste material other than moving or discarding? How do we provide space-building that could accommodate piles of waste material and not raise the same issues in the future? Both questions were processed in the same time in an integrated way. At last, the final solution chosen was to put the waste materials into use, which was originally the source of the problem and now becomes the major source of solution. The main concept of the solution was the transformation of the problem object that required space into the solution object by making the problem object become the space needed. The preferred solution is the end of the stage of problem identification and solution discovery. Figure 1 shows a chart of the thinking process towards the discovery of the solution:

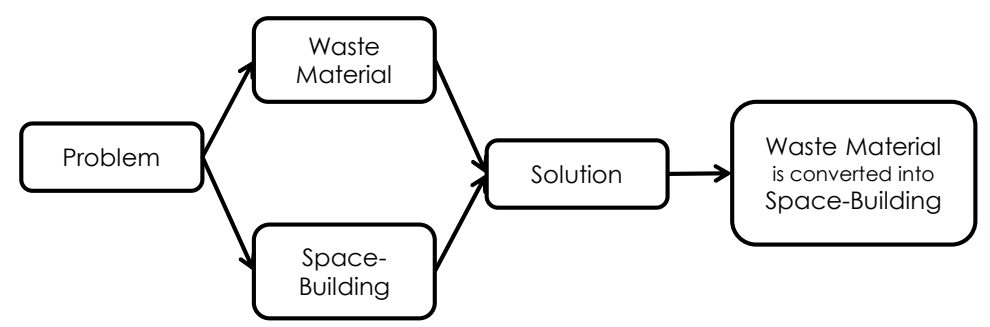

Figure 1: $\quad$ Process of problem identification and solution discovery for 'Rempah Rumah Karya'

\subsection{Interpretation}

Interpretation was initiated by observing and inventorying the existing waste construction materials. Making an inventory was done by recording the detail of each piece of waste material and classifing the remaining pieces of material into respective types, characters, and dimensions. Inventory and classification of waste material generated a complete data about the type, character, dimensions and the amount of any remaining piece of material. These data were used as instruments in the process of interpretation towardsthe existence of waste materials and their potentials.

Paulus Mintarga as the architect contemplated on the waste construction materials: metal rods, demolition planks, pieces of waste wood furnishing, harmonica netting, plastic, etc. The waste materials were allowed to 'talk' about their natural appearance and existence in term of character, size (width, thickness, 
length) and others. Based on their 'story', the architect was looking for ways to assist them to preen appropriate physical conditions of existence and uniqueness of each. At this stage, the reuse of waste material principle applies to any existing pieces of material that could be found.

The interpretation stage was dominated by the process of understanding through letting and listening to materials 'talk', so the architect can help them primp. This is to build a harmony and form a synergy in their new form that may have never existed before. The experience to be willing to let and listen to the waste materials 'talk' about themselves as they are is the abstraction of the spiritual experience of the architect while self-harmonising with the waste materials.

In general, architects and designers have started the interpretation process of materials in conditions of new materials with specific modules. New materials with specific modules influenced this process effectively and efficiently, both in the calculation of material requirements, price, and working time. In general conditions, often the interpretation phase of material produces unique creativities as the result of the architect or designer's creative thinking. At different conditions, if the material is a waste material, it would require more creativity from the architect or designer to be able to finish it. The result will certainly be more unique because they may not be repeated with the same product.

This interpretation stage is a stage that produces the interpretation of the basic principles underlying the process and subsequent design decisions. At this stage, in the context of the design thinking process of 'Rempah Rumah Karya' the following principles had appeared:

- Reuse waste material as a whole if possible.

- Creation by contemplating on the natural appearance of the waste materials and their existences in terms of character, size, and others.

- Waste material reconstructed into new construction.

\subsection{Ideation}

Ideation was initiated by having ideas and concepts in the form of schematic design of the shapes that may be produced from each alloy waste material that has been inventoried. Ideation process is led by the architect with a sensitivity of technical intuition and logic. Formation and construction that might arise from the alloy composition of waste material was ordered by the design team for the preliminary sketches. The idea of conceptual sketches arised from the availability of waste materials those were equipped with data of size and amount.

The ideation stage is often more liberal and flexible in order to optimally invent all possible forms that could be produced, starting from the new modular material and the amount that can be fitted to the needs. In the context of the design thinking process for 'Rempah Rumah Karya', ideation was performed by the limitation of the waste material availability with the data dimensions that were ununiform and limited in number. Conceptual sketches were processed from the reference of available material data. Figure 2 shows some results of the final ideation stage of 'Rempah Rumah Karya': 

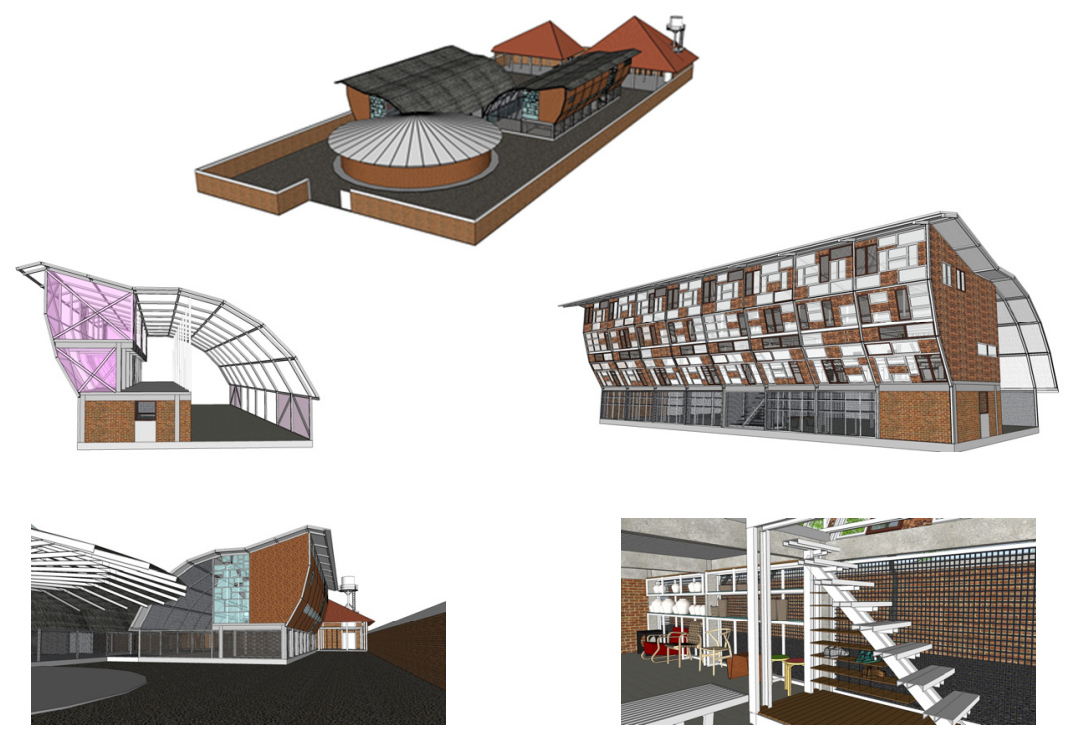

Figure 2: Concept sketches of 'Rempah Rumah Karya'.

\subsection{Experimentation}

Experimentation was started by realizing ideas and concepts and to test them out in the form of schematic design of every possible form that could become a logical structural construction as the basic structure of the building-space to be designed. Experimental works in the 'Rempah Rumah Karya' design thinking process were carried out through the architect's civil engineering scientific experience. Some tests and simulations of the real physical formation of the waste materials were done to find the composition producing visual aesthetics and to search for the most optimal construction to apply.

Test and simulation were performed using each waste material suitable in type, character and dimensions. A lot of waste materials in the form of steel rods with various dimensions of length were trialed to be used as main building frames with no attempt to alter or cut. They were connected by following the corners of the end of each steel. Waste materials in the form of steel rods were maintained as they were with the angled end pieces formed possibilities of harmonius construction. Roof constructions using steel rod materials are generally straight, however, in the case of 'Rempah Rumah Karya' it could become curved because of the connection between the angular steel bars.

Waste materials in the form of wood pieces were left as what they were and attached one by one in a frame to form the artistically textured shapes. Irregular iron sheets and small metal rods waste materials were used to form a composition of positive-negative shapes. A trial was made with the floor materials in using 
woven bamboo and styreofoam or polystyrene with cement plaster finishing. Bamboo was used as a buffer material in the base layer of the roof and floor plates. Styreofoam plates were used instead of reinforcing the floor while bags of cement painted with asphalt and palm fibers became alternative materials for the roof. Disused former windows, waste brick, and wood in a variety of sizes were mixed to create an interesting mosaic composition on the building shell.

At this experimental stage, the main concern is aesthetic sensibility and strong logic of construction to produce a form that would not only appear beautiful but also must be sturdy. Figure 3 shows some examples of the results of the experimentation on waste materials that were achieved:
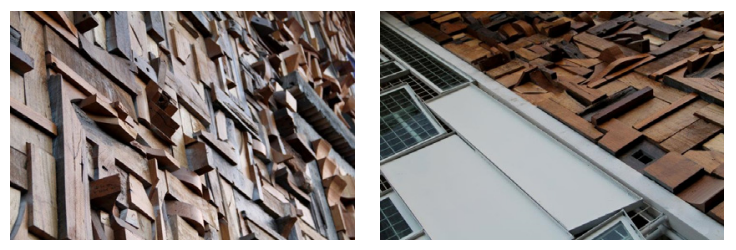

Figure 3: Aesthetical and constructive experiment using waste materials.

\subsection{Evolution}

Evolution, started from carrying out real development of ideas and design concepts decisions to achieve the resulted design form of space and building. Real construction starts from the establishment of the test result of steel rods as the main frame or structure to become the contours of the space-building. Following the formation of the main frame is the implementation of enclosures made up of waste materials that have been previously experimented, marking the beginning of the construction process of 'Rempah Rumah Karya' space-building (Figure 4):
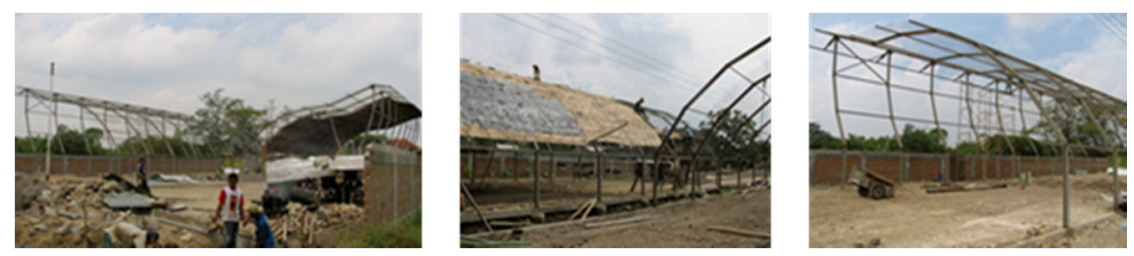

Figure 4: Starting construction of 'Rempah Rumah Karya' [7].

Eventually, most of the waste materials were evolved into a house full of artistic taste, not as a private house but as a workshop for a variety of creative activities in the field of arts, design, and culture, named 'Rempah Rumah Karya'. Figure 5 reveals the final embodiment of the 'Rempah Rumah Karya': 

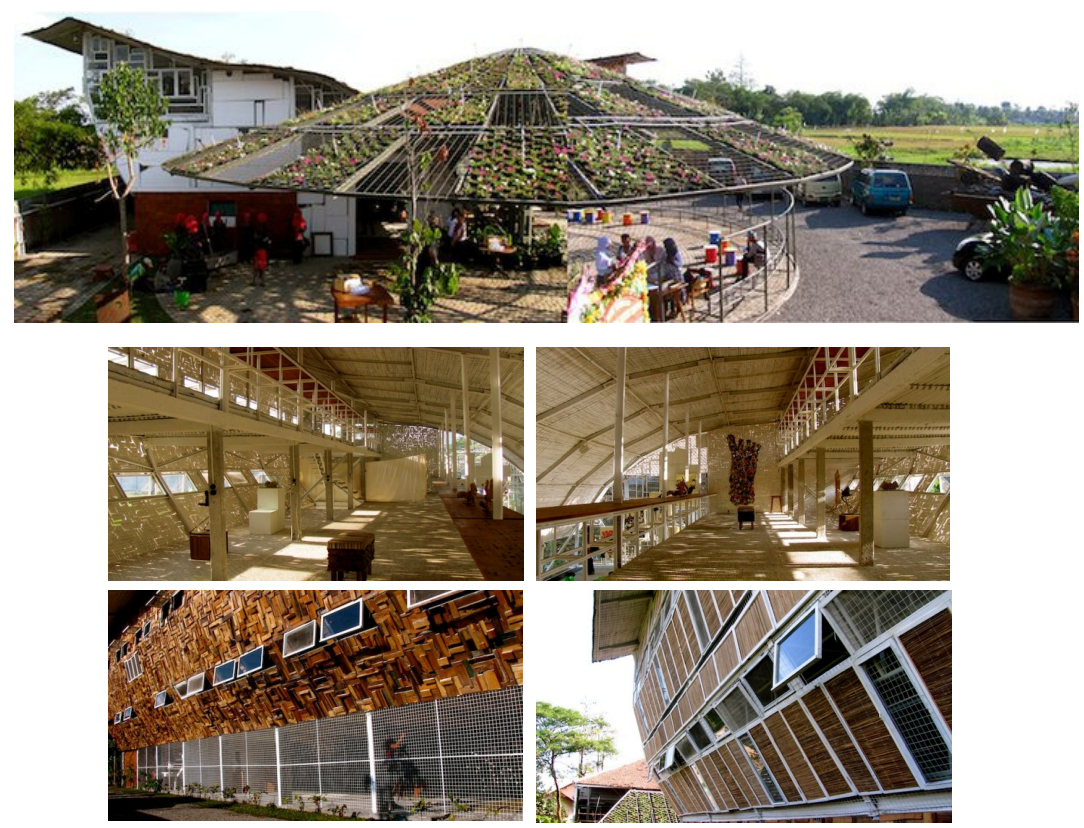

Figure 5: 'Rempah Rumah Karya' documentation [7].

\section{Self critical design of 'Rempah Rumah Karya'}

"Rempah (Spices)" in Bahasa Indonesia means "Remukan Sampah (Crushed Trash)". This Rumah Karya (House of Work) was 90\% built from waste materials in the owner warehouse. Currently there are four buildings (one for the warehouse and workshop, one for the dorm, and two buildings for offices, laboratories, space design, showrooms and conference rooms). 'Rempah Rumah Karya'was dedicated to the creative works in the city of Solo and the surrounding areas. 'Rempah Rumah Karya' is the place for community to explore and create. Over there, people gather to develop their creativity and form a synergy to improve the city's productivity.

The scope of creative work established in 'Rempah Rumah Karya'covers a wide range of important elements and design fields: starting from the design and structure of the materials; architecture, interior design; furniture design: product design; art and craft; inventory of sustainable local-natural materials which is aimed towards an applicable resource directory; mechatronics and informatics; environmentally alternative energy; to environmental-cultural education.

'Rempah Rumah Karya' space-building is a result of an experimental design thinking process of reusing waste materials with all their limitations. Therefore, it needs to be maintained and evaluated regularly in order to achieve optimum function and to be able to apply design construction that support the productivity 
of any creative activity conducted within. Results of the evaluation after one year post-occupancy in the 'Rempah Rumah Karya' space-building are:

- The space-building has become an embodiment of a unique creative house 'Rempah Rumah Karya' as an object studied by architects and interior designers in Indonesia as well as a living laboratory of applied ecological materials.

- The application of the main construction of 'Rempah Rumah Karya' is generated by pieces of steel bars and the lining of the walls from pieces of waste wood and metal strong enough to sustain its function.

- The outer layer of the roof of 'Rempah Rumah Karya' which was made up of palm fiber is quite prone to fire when it contact with flame and thus needs to supervised while also minimising the source of fire leading to inside and outside the building.

- A layer of roof using asphalt melted at daytime temperature (especially in the dry season) because it was very hot, which led to a special concern. The temporary solution suggested was to add another layer at the bottom of the roof with a thick cloth to hold the melt and reduce the heat into the interior.

Apart from the above report, more self-critical report of the design of 'Rempah Rumah Karya' will always take place throughout use in future. The goal is an evaluation of what have been applied in the physical space from waste materials. The results of these evaluations would be very beneficial to the development of science and practice of architecture and interior design, especially for design learners in Indonesia.

\section{Conclusion}

The physical existence of 'Rempah Rumah Karya' has greatly enriched the wealth of space-building creativity in Indonesia and has become a beacon of learning for architecture and interior design of ecological building. Program activities accommodated at the 'Rempah Rumah Karya' have been very useful in encouraging creativity in social, cultural, and economic fields. As a whole, the 'Rempah Rumah Karya' has become one of the communities that has contributed to the effort of implementating sustainable design.

The sustainable design principles developed from 'Rempah Rumah Karya' can be summed up into' $6 \mathrm{M}$ ':

- 'Murah' (Cheap), in association with the required fee from the production, distribution, and operational use and maintenance.

- 'Mudah' (Easy), in terms ofthe requirements for production, distribution, operational use, and maintenance.

- 'Mutu' (Quality), with regard to quality of products produced.

- 'Memuaskan' (Satisfactory), with regard to user satisfaction towards the optimal function of the space-building. 
- 'Masyarakat' (Society), with regard to the impact and benefits produced primarily in the economical aspect, in terms of community empowerment through involvement in the production and distribution process.

Sustainable design at the 'Rempah Rumah Karya' began its achievement by first allowing 'material to talk about themselves' and then the architect assisted in combining them into a harmonious appearance and form a synergy. Harmony was manifested in the beauty of form, while synergy rendered quality. With the success it has achieved, it is hoped that this tale of the design thinking process of 'Rempah Rumah Karya' would be a reference of transforming the so-called waste materials into a magnificient creative house capable of inspiring the society (a case of adapted reuse).

\section{Acknowledgements}

This research is part of the Competitive Research Grant 2014 program funded by the Directorate of Research and Community Service, Ministry of Education and Culture of Indonesia. For the motivation, support and financing, we would like to say thank you.

\section{References}

[1] Prima Putra Bengawan: Crafting Wood Creations, Furniture, and Design, http://www.primaputra.com

[2] Riverdale \& IDEO., Design Thinking for Educators, pp. 4, 2011.

[3] Lockwood, Thomas, Design Thinking: Integrating Innovation, Customer Experience, and Brand Value, New York: Allworth Press, pp. 50, 2010.

[4] Tim Brown, Change by Design, New York: Harper Collins Publishers, p. 16, 2009.

[5] Ambrose, Gavin and Harris, Paul, Design Thinking. Switzerland: AVA Publishing, pp 12, 2010.

[6] Lawson, Bryan, How Designers Think: The Design Process Demystified, Oxford: Architectural Press is an imprint of Elsevier. $4^{\text {th }}$ edition, pp. 34, 2005. Rempah Rumah Karya, http://ruang17.wordpress.com/2011/07/10/rempah$\underline{\text { rumah-karya/ }}$ 